Radiocarbon, Vol 25, No. 1, 1983, P 152-168]

\title{
UNIVERSITY OF WISCONSIN RADIOCARBON DATES XX
}

\author{
RAYMOND L STEVENTON and JOHN E KUTZBACH
}

Center for Climatic Research, Institute for Environmental Studies, University of Wisconsin-Madison, 1225 West Dayton Street, Madison, Wisconsin 53706

Procedures and equipment have been described in previous date lists. Except as otherwise indicated, wood, charcoal, and peat samples are pretreated with dilute $\mathrm{NaOH}-\mathrm{Na}_{4} \mathrm{P}_{2} \mathrm{O}_{7}$ and dilute $\mathrm{H}_{3} \mathrm{PO}_{4}$ before conversion to the counting gas methane; marls and lake cores are treated with acid only. Very calcareous materials are treated with $\mathrm{HCl}$ instead of $\mathrm{H}_{3} \mathrm{PO}_{4}$. Pretreatment of bone varies with the condition of the bone sample; solid bone with little deterioration is first cleaned manually and ultrasonically. The bone is treated with $8 \% \mathrm{HCl}$ for 15 minutes, then dilute $\mathrm{NaOH}-$ $\mathrm{Na}_{4} \mathrm{P}_{2} \mathrm{O}_{7}$ for 3 hours at room temperature, washed until neutral, and the collagen extracted according to Longin (1971). Charred bone is treated with dilute $\mathrm{HCl}, \mathrm{NaOH}-\mathrm{Na}_{4} \mathrm{P}_{2} \mathrm{O}_{7}$, and then dilute $\mathrm{HCl}$ again.

The dates reported have been calculated using 5568 as the half-life of ${ }^{14} \mathrm{C}$. The standard deviation quoted includes only $1 \sigma$ of the counting statistics of background, sample, and standard counts. Background methane is prepared from anthracite, standard methane from NBS oxalic acid. The activities of the dated samples for which $\delta^{13}$ values are listed have been corrected to correspond to a $\delta^{13} \mathrm{C}$ value of $-25 \%$; the activity of the standard methane has been corrected to $-19 \%$.

Sample descriptions are based on information supplied by those who submitted samples.

\section{ACKNOWLEDGMENTS}

This research is supported by the National Science Foundation under Grant \#ATM-7926039. We thank the Chemistry Department for the use of the RMS 6-60 mass spectrometer. We also wish to thank David Weeden for his technical assistance.

\section{ARCHAEOLOGIC SAMPLES}

Missouri

\section{United States}

\section{Feeler site (23Ms12) series}

Samples from Feeler site in Maries Co $\left(38^{\circ} 07^{\prime} 30^{\prime \prime} \mathrm{N}, 91^{\circ} 52^{\prime} 30^{\prime \prime} \mathrm{W}\right.$ ) coll 1978 and 1981 and subm by R L Reeder, Univ Missouri, Columbia. Samples date Late Woodland village at which wide range of cultigens were found.

WIS-1400.

$$
920 \pm 70
$$

Oak wood charcoal from Feature 76 , small hearth $45 \mathrm{~cm}$ diam and $15 \mathrm{~cm}$ deep. Hearth matrix consisted of mixed rock, silt, charcoal flecks, and chunks. Top of hearth was ca $5 \mathrm{~cm}$ below base of plow zone. Sample was 8 to $9 \mathrm{~cm}$ below base of plow zone. 
WIS-1402.

$860 \pm 70$

Oak wood charcoal from Feature 37, Level 4, large cylindrical trash pit, $80 \mathrm{~cm}$ diam, depth $56 \mathrm{~cm}$ from base of plow zone. Level 4 was a black moist soil of silt and large amounts of charcoal, rich in cultural material.

\section{South Dakota}

\section{Smiley-Evans site (39Bu2) series}

Samples from Smiley-Evans site, large fortified campsite in Butte Co $\left(44^{\circ} 40^{\prime} \mathrm{N}, 103^{\circ} 50^{\prime} \mathrm{W}\right.$ ) coll in 1979 and 1980 and subm by $\mathrm{L} \mathrm{M}$ Alex, South Dakota Archaeol Research Center, Ft Meade. Excavation revealed fortification stockade and ditch with peripheral structure and over 20 features of hearth/roasting/cooking pit variety. Artifacts and features suggest some resemblance to those of Initial Variant of Middle Missouri tradition (Alex, 1979).

WIS-1346.

$1070 \pm 70$

Wood charcoal from Feature 14a-1, Level 5 of large, fired, bell-shaped roasting pit containing much faunal material, fire-cracked rock, burned earth, and charcoal in Sq E45N5.

WIS-1347.

$$
900 \pm 70
$$

Wood charcoal from Feature 18, Level 3 of large, fired, slightly bellshaped roasting pit containing faunal material, fire-cracked rock, burned earth, and charcoal in Sq E14S22.

WIS-1348.

$1190 \pm 70$

Wood charcoal from Feature 12, Level 2 of large, straight-sided pit containing faunal material, fire-cracked rock and some charcoal in Sq E26N7.

WIS-1349.

$980 \pm 70$

Wood charcoal from Feature 14a-2, Level 5 of large, fired, bell-shaped roasting pit containing much faunal material, fire-cracked rock, burned earth, and charcoal in Sq E45N5.

WIS-1350.

$$
960 \pm 70
$$

Charred wood and charcoal from Level 4 at base of man-made ditch in Sq W4S0. Level 4 consisted of concentrated midden in dark organic matrix overlain by sandy fill and underlain by white sand containing caliche.

WIS-1351.

$810 \pm 70$

Twelve $\mathrm{cm}$ segment cut from wooden post (Post G) in postulated stockade at $\mathrm{W}$ edge of site, from Sq W0S4. Post contained 15 rings, no bark remaining.

WIS-1352.

$930 \pm 70$

Ten $\mathrm{cm}$ sample cut from center of wooden post (Post S) found in structure peripheral to postulated stockade at $\mathrm{W}$ edge of site, from Sq 
E0S6. Rock wedge occurred adjacent to post remnant. Post contained 18 rings, no bark remaining.

\section{Winter site (39De5) series}

Samples from Winter site at Coteau Lake, Deuel Co $\left(44^{\circ} 50^{\prime} \mathrm{N}, 96^{\circ}\right.$ $43^{\prime}$ W) coll 1980 and 1981 by Betty Sterner and J K Haug; subm by J K Haug, South Dakota Archaeol Research Center. Artifacts and features recovered suggest numerous occupations, from Paleo-Indian through late prehistoric. Excavations concentrated largely on Middle and Late Woodland cultures.

WIS-1358.

Wood charcoal from Feature 1, large conoidal cache pit at $1 \mathrm{~N} 6 \mathrm{E}$, containing fire-cracked rock, faunal material, and ceramics.

WIS-1359.

$$
1180 \pm 70
$$

Wood charcoal from Feature 2, shallow rock-filled hearth 50 to $60 \mathrm{~cm}$ below ground surface, $3 \mathrm{~m} \mathrm{~S}, 5 \mathrm{~m} \mathrm{E}$ of datum site. Feature contained faunal material, fire-cracked rock, ceramics, and lithic artifacts.

WIS-1371.

$1110 \pm 70$

Wood charcoal from Feature 4a, part of Feature 4, Level 2, large cache pit $11 \mathrm{~m} \mathrm{~N}, 18 \mathrm{~m} \mathrm{~W}$ of site datum. Sample taken from 62 to $92 \mathrm{~cm}$ below surface.

WIS-1372.

$$
1250 \pm 70
$$

Wood charcoal from Feature 4, Level 2, large cache pit. Sample from 52 to $62 \mathrm{~cm}$ below surface. Feature contained faunal remains, ceramics, fire-cracked rock, and lithic materials.

WIS-1373.

$$
1950 \pm 70
$$

Wood charcoal from Feature 3, Level 2, shallow rock-filled basin $10.5 \mathrm{~m} \mathrm{~N}, 15 \mathrm{~m} \mathrm{~W}$ of site datum. Feature contained faunal remains, ceramics, fire-cracked rock, and lithic materials.

WIS-1369. Miner Rattlesnake site (39Cu417)

$\mathbf{2 3 7 0} \pm \mathbf{7 0}$

Wood charcoal from hearth in stone circle \#2, Custer Co $\left(43^{\circ} 49^{\prime} 30^{\prime \prime}\right.$ $\left.\mathrm{N}, 103^{\circ} 12^{\prime} 55^{\prime \prime} \mathrm{W}\right)$ coll 1981 and subm by D M Hovde, South Dakota Archaeol Research Center. Sample recovered from basin-shaped hearth, $7 \mathrm{~cm}$ deep, in center of stone circle. Highly friable large mammal longbone was found near hearth and is assoc with occupation of stone circle (Hovde, 1981).

\section{Hartford Beach Village site (39Ro5) series}

Samples from Hartford Beach Village site, Robert Co $\left(45^{\circ} 24^{\prime} \mathrm{N}, 96^{\circ}\right.$ $4 \mathrm{l}^{\prime} \mathrm{W}$ ) coll $198 \mathrm{l}$ and subm by $\mathrm{J} \mathrm{K}$ Haug. Site is small fortified village on high bluff above Big Stone Lake. Evidence of bastioned fortification and palisade was uncovered. Earth lodge depressions were not present, but cache pit, hearths, and isolated post holes were found. Ceramics and other elements suggest similarities to Initial Variant of Middle Missouri 
tradition. Samples are from large bell-shaped cache pit 23 to $120 \mathrm{~cm}$ below surface, $10 \mathrm{~m} \mathrm{~N}, 5 \mathrm{~m} \mathrm{~W}$ of site datum.

WIS-1368.

$830 \pm 70$

Wood charcoal from Feature 3, Level 2,33 to $120 \mathrm{~cm}$ below surface.

WIS-1370.

$650 \pm 70$

Wood charcoal from Feature 3, Level 1, 23 to $33 \mathrm{~cm}$ below surface.

\section{Dirt Lodge Village site (39Sp11) series}

Samples from Dirt Lodge Village site on James $\mathrm{R}$ in Spink Co $\left(44^{\circ}\right.$ $55^{\prime} \mathrm{N}, 98^{\circ} 29^{\prime} \mathrm{W}$ ) coll in 1980 and 1981 and subm by $\mathrm{T}$ W Haberman, South Dakota Archaeol Research Center. Three major components are present including occupations by Woodland, Plains Village, and Historic Dakota populations. Dates are expected to correspond with those from Initial Middle Missouri tradition sites further $S$ on James $R(R, 1973$, v 15, p 235, 618).

WIS-1374.

$\mathbf{7 7 0} \pm \mathbf{7 0}$

Wood charcoal from Feature 16, Levels 4 and 5, refuse-filled cache pit.

WIS-1375.

$920 \pm 70$

Wood charcoal from Feature 6, refuse-filled cache pit.

WIS-1376.

$\mathbf{7 0 0} \pm \mathbf{7 0}$

Wood charcoal from Feature 16, Levels 7 and 8, refuse-filled cache pit.

WIS-1377.

$1410 \pm 70$

Wood charcoal from Feature 125, Level 3, roasting hearth.

Tennessee

\section{Tuskegee Pond series}

Core coll from Tuskegee Pond, Monroe Co $\left(35^{\circ} 35^{\prime} \mathrm{N}, 84^{\circ} 12^{\prime} \mathrm{W}\right)$ by P A Delcourt; subm by P A Delcourt, Univ Tennessee, Knoxville. Dates provide chronologic context for fossil-pollen sequence obtained from Tuskegee Pond for correlation with the archaeol record of human occupation at nearby Icehouse Bottom site (Delcourt, 1980; Chapman and Shea, 1981). Samples were slightly calcareous and were acid treated only.

WIS-1306.

Clayey silt, 170 to $175 \mathrm{~cm}$ below water surface.

\section{WIS-1307.}

Silty clay, 130 to $136 \mathrm{~cm}$ below water surface.

WIS-1313.

Clayey sandy silt, 195 to $212 \mathrm{~cm}$ below water surface.

$$
\mathbf{2 5 0} \pm \mathbf{7 0}
$$$$
\delta^{13} \mathrm{C}=-25.7 \% \text { 。 }
$$

$200 \pm 70$

$\delta^{13} C=-26.2 \%$

$1630 \pm 80$ 
Wisconsin

WIS-1272. Ambro I site (47Cr350)

$960 \pm 80$

Charcoal from site in Crawford Co $\left(43^{\circ} 04^{\prime} \mathrm{N}, 91^{\circ} 09^{\prime} \mathrm{W}\right)$ coll Aug 1980 and subm by J B Stoltman, Univ Wisconsin-Madison. Sample was taken from Shell Lens A, 48 to $66 \mathrm{~cm}$ below surface. Date should apply to shellfish gathering of early participants in Effigy Mound culture in Prairie du Chien area. Directly assoc is uncollared vessel of Madison Cord-Impressed type.

WIS-1312. Hunter Channel II (47Cr313b)

$1790 \pm 90$

Charcoal from site in Crawford Co $\left(43^{\circ} 04^{\prime} \mathrm{N}, 91^{\circ} 09^{\prime} \mathrm{W}\right)$ coll Oct 1979 by J Theler; subm by J B Stoltman. Sample was from Feature 1, triangular pit in plain view, exposed by erosion, $130 \mathrm{~cm}$ below top of river bank on Hunter Channel on Mississippi R. Top of eroded feature contained Lane Farm (rocker) stamped rimsherd.

Mill Pond series (47Cr186)

Samples from site in Crawford Co $\left(43^{\circ} 04^{\prime} 30^{\prime \prime} \mathrm{N}, 91^{\circ} 09^{\prime} 45^{\prime \prime} \mathrm{W}\right.$ ) coll Aug 1980 by J Theler and C Arzigian; subm by J B Stoltman.

WIS-1276.

$1880 \pm 80$ (1) $90 \mathrm{~cm}$ below surface, $2 \mathrm{~m} \mathrm{~N}$ of exposed Early Woodland shell midden. Date applies to newly defined Prairie phase, local manifestation of Black Sand culture (WIS-1291: R, 1982, v 24, p 86).

WIS-1310.

$\mathbf{8 6 0} \pm \mathbf{8 0}$

$\delta^{13} C=-26.3 \%$

Charcoal from Feature 23, $98 \mathrm{~cm}$ below surface, $30 \mathrm{~cm}$ diam, 20 to $30 \mathrm{~cm}$ deep. Date applies to 1 st occurrence of corn with Late Woodland ceramics, not only in Prairie du Chien area, but in Upper Mississippi Valley outside of Illinois. Assoc ceramics, with slightly thickened lips and cord-impressing on both interior and exterior lip/rim junctures, look typologically later than comparable rims from 47Cr350 (WIS-1272).

WIS-1311.

$1030 \pm 80$

Charcoal from Feature $13,84 \mathrm{~cm}$ below surface overlying Middle Woodland shell lens. Feature contained burned floral and faunal remains, including charred corn and Madison Ware ceramics. Sample dates unusual occurrence of corn and Late Woodland ceramics in Prairie du Chien area.

\section{Mill Coulee Shell Heap (47Cr100) series}

Charcoal from site in Crawford Co $\left(43^{\circ} 04^{\prime} \mathrm{N}, 91^{\circ} 09^{\prime} \mathrm{W}\right)$ coll 1980 by J Theler and C Arizigian; subm by J B Stoltman. Dates provide earliest evidence of seasonally sedentary habitation in terrace settings above flood plain in Prairie du Chien area. Ceramics and projectile points coll from surface and features place site in Millville phase (Stoltman, 1979) (WIS-1249, -1290, R: 1982, v 24, p 86). 
WIS-1308.

$1620 \pm 70$

Sample from Feature 4 immediately adjacent to large clamshell pit (Feature 3), feature is $5 \mathrm{~cm}$ below plow zone in Sq 3.

WIS-1335.

$1670 \pm 70$

Sample from Feature 3, basin-shaped feature filled with naiad shells, bones, charcoal, and burned rock.

WIS-1309. Dillman I (47Cr348)

$1890 \pm 80$

Charcoal from site in Crawford Co $\left(43^{\circ} 04^{\prime} \mathrm{N}, 91^{\circ} 09^{\prime} \mathrm{W}\right)$ coll July 1980 by R Boszhardt; subm by J B Stoltman. Sample was coll from soil surrounding vessel that had collapsed upon itself. Silty loam soil contained charcoal and ceramic sherds all from vessel. Date applies to newly defined Prairie phase, local manifestation of Black Sand culture (WIS-1291: R, 1982, v 24, p 86).

WIS-1336. Quarter Mile Shell Midden (47Cr310) $1150 \pm 70$

Charcoal from site in Crawford Co $\left(43^{\circ} 04^{\prime} \mathrm{N}, 91^{\circ} 09^{\prime} \mathrm{W}\right)$ coll Aug 1980 by R Boszhardt; subm by J B Stoltman. Sample from base of extensive shell midden, $120 \mathrm{~cm}$ below surface. Date should approximate beginnings of shift from small-scale shellfish collecting to intensive, large-scale exploitation. Apparently assoc with this shift was settlement change from low floodplain camps to residential terrace villages and affiliated, nonresidential extraction stations (for shell fish) in low flood plain. This date is also of geol significance in that it is assoc with shell fish derived from active river channel that is now backwater slough.

\section{Oak Lake site (47Fr143) series}

Charcoal from site in Forest Co $\left(45^{\circ} 28^{\prime} 32^{\prime \prime} \mathrm{N}, 88^{\circ} 55^{\prime} 57^{\prime \prime} \mathrm{W}\right)$ coll Oct 1981 by D Overstreet; subm by D Overstreet and L Brazeau, Great Lakes Archaeol Research Center, Waukesha. Samples were from sealed pit lenses assoc with lithic materials attributed to single component Lakes phase occupation (Salzer, 1969; 1974). Two of 43 refuse/storage pits were sampled. Site (47Fr 143) is undisturbed; origins of pits are still visible on surface. Large storage facility areas have not been heretofore reported for Lakes phase sites (Overstreet, 1981).

WIS-1339.

$750 \pm 70$

Sample from Pit 6 at interface between burned pit fill and ash sand layer forming pit boundaries.

WIS-1340.

$830 \pm 70$

Sample from Pit 8 at uppermost burned layer of pit fill. Profile suggests this is intrusive episode into earlier use of pit. Burned layer is stratigraphically above 3 additional burned layers that are separated by ashy sand layers. 


\section{WIS-1378. Poor Man's Farrah site (47Gt366)}

$1030 \pm 70$

Wood charcoal from Poor Man's Farrah site $\left(42^{\circ} 30^{\prime} 55^{\prime \prime} \mathrm{N}, 90^{\circ} 37^{\prime}\right.$ $31^{\prime \prime}$ W) coll by C Erickson and J Penman; subm by J Penman, State Hist Soc Wisconsin, Madison. Site is one of several Late Woodland mound groups on bluff tops above Mississippi $\mathrm{R}$ ca $2 \mathrm{~km} \mathrm{~N}$ of Illinois state line. Sample is from feature below mound fill and may provide date of mound construction.

\section{Connecticut}

\section{GEOLOGIC SAMPLES}

\section{United States}

\section{Lantern Hill Pond series}

Core coll Sept 1980 from Lantern Hill Pond, New London Co $\left(41^{\circ}\right.$ $27^{\prime} 30^{\prime \prime} \mathrm{N}, 71^{\circ} 57^{\prime} \mathrm{W}$ ) by K McGown et al. Subm by T Webb, III, Brown Univ, Providence, Rhode Island. Water depth $10 \mathrm{~m}$. Dates previously reported (R, 1982, v 24, p 89).

\section{WIS-1344.}

$6220 \pm 80$

Gyttja, 607 to $613 \mathrm{~cm}$ below sediment surface.

\section{WIS-1345.}

$4000 \pm 80$

Gyttja, 377 to $383 \mathrm{~cm}$ below sediment surface.

\section{WIS-1405. Mohawk Pond}

Livingstone core, $5 \mathrm{~cm}$ diam, coll Jan 1982 from Mohawk Pond, Litchfield Co $\left(41^{\circ} 49^{\prime} \mathrm{N}, 73^{\circ} 17^{\prime} \mathrm{W}\right)$ by D C Gaudreau et al, subm by D C Gaudreau, Brown Univ. Gyttja 1179 to $1183 \mathrm{~cm}$. Basal date for Holocene pollen analysis.

\section{Massachusetts}

\section{Duck Pond series}

Core $4.5 \mathrm{~m}$, coll June 1980 from Duck Pond, Barnstable Co $\left(41^{\circ} 50^{\prime}\right.$ $\left.\mathrm{N}, 70^{\circ} 00^{\prime} \mathrm{W}\right)$, subm by $\mathrm{M}$ Winkler, Univ Wisconsin-Madison. Water depth $18.2 \mathrm{~m}$. Dates previously reported on this site $(\mathrm{R}, 1981, \mathrm{v} 23$, p 153154) (R, 1982, v 24, p 90).

\section{WIS-1318.}

$9140 \pm 100$

Gyttja, 2138 to $2142 \mathrm{~cm}$ below water surface.

WIS-1391.

$$
8230 \pm 90
$$

Gyttja, 2070 to $2075 \mathrm{~cm}$ below water surface.

\section{Tom Swamp series}

Core coll Nov 1979 from Tom Swamp, Harvard Forest, Worchester Co $\left(42^{\circ} 31^{\prime} \mathrm{N}, 62^{\circ} 13^{\prime} \mathrm{W}\right)$ by C Lenk et al, subm by $\mathrm{T}$ Webb. Pollen diagram from Tom Swamp was pub (Davis, 1958). Dates on other levels were reported ( $R, 1982$, v 24, p 89). 
WIS-1321.

$6920 \pm 80$

Herbaceous peat with some ligneous detritus, 465 to $469 \mathrm{~cm}$ deep, dates events in "oak" zone.

WIS-1322.

$7280 \pm 80$

Herbaceous peat with some ligneous detritus, 565 to $569 \mathrm{~cm}$ deep, dates events in "oak" zone.

WIS-1323.

$6080 \pm 80$

Herbaceous and ligneous peat, 336 to $340 \mathrm{~cm}$ deep, dates events in "oak" zone.

\section{Minnesota}

WIS-1303. Wentzel's Pond

$$
\begin{array}{r}
\mathbf{8 0 0} \pm \mathbf{8 0} \\
\delta^{13} C=-29.6 \%
\end{array}
$$

Livingstone core, $5 \mathrm{~cm}$ diam, from Wentzel's Pond, Hubbard Co $\left(46^{\circ}\right.$ $57^{\prime} \mathrm{N}, 94^{\circ} 57^{\prime} \mathrm{W}$ ). Coll March 1980 by J C Almendinger et al; subm by J C Almendinger, Univ Minnesota, Minneapolis. Slightly calcareous algal copropel with occasional snail shell, 75 to $80 \mathrm{~cm}$ below sediment surface. Water depth $157 \mathrm{~cm}$; sediment thickness $4 \mathrm{~m}$ over glacial outwash. Increase of pine pollen at this level marks development of jack pine forest on this sec of Park Rapids-Staples outwash plain. Dates from several sites will be compared to test hypothesis that jack pine forests invaded patches of Minnesota's outwash plains at various times throughout Holocene. Acid treatment only.

WIS-1304. Lake Moran

$$
\begin{array}{r}
2460 \pm 80 \\
\delta^{13} C=-24 \% \circ
\end{array}
$$

Livingstone core, $5 \mathrm{~cm}$ diam, from Lake Moran, Hubbard Co $\left(46^{\circ} 51^{\prime}\right.$ $\left.\mathrm{N}, 95^{\circ} 04^{\prime} \mathrm{W}\right)$. Coll March 1980 by J C Almendinger et al; subm by J C Almendinger. Algal copropel, 280 to $290 \mathrm{~cm}$ below sediment surface. Water depth $471 \mathrm{~cm}$; sediment thickness $14 \mathrm{~m}$ over glacial outwash. Same observations as for WIS-1303, above. Acid treatment only.

\section{WIS-1305. Mud Lake}

$3060 \pm 80$

$\delta^{13} \mathrm{C}=-27.9 \%$

Livingstone core, $5 \mathrm{~cm}$ diam, from Mud Lake, Hubbard Co $\left(46^{\circ} 52^{\prime}\right.$ $\mathrm{N}, 94^{\circ} 45^{\prime} \mathrm{W}$ ). Coll March 1980 by J C Almendinger et al; subm by J C Almendinger. Algal copropel, 330 to $340 \mathrm{~cm}$ below sediment surface. Water depth at $827 \mathrm{~cm}$; sediment thickness $10 \mathrm{~m}$ over glacial outwash. Same observations as for WIS-1303, above. Acid treatment only.

\section{WIS-1314. Hostage Lake}

$1870 \pm 80$

Livingstone core, $5 \mathrm{~cm}$ diam, from Hostage Lake, Crow Wing Co $\left(46^{\circ}\right.$ $\left.33^{\prime} \mathrm{N}, 94^{\circ} 08^{\prime} \mathrm{W}\right)$. Coll March 1981 by J C Almendinger et al; subm by J C Almendinger. Algal copropel, 215 to $225 \mathrm{~cm}$ below sediment surface. Water depth $151 \mathrm{~cm}$; sediment thickness $7 \mathrm{~m}$ over glacial outwash. Increase of pine pollen at this level marks development of jack pine forest on this sec of Crow Wing outwash plain. Same observations as for WIS-1303, above. Acid treatment only. 
Livingstone core, $5 \mathrm{~cm}$ diam, from Big John Pond, Beltrami Co $\left(47^{\circ}\right.$ $33^{\prime} 30^{\prime \prime} \mathrm{N}, 94^{\circ} 58^{\prime} \mathrm{W}$ ). Coll Feb 1981 by J C. Almendinger et al; subm by $\mathrm{J} \mathrm{C}$ Almendinger. Calcareous algal copropel with occasional shell, 60 to $65 \mathrm{~cm}$ below sediment surface. Water depth measured at $60 \mathrm{~cm}$ and sediment thickness $450 \mathrm{~cm}$ over glacial outwash. Increase of pine pollen at this level marks development of jack pine forest on this sec of Bemidji sand plain. Same observations as for WIS-1303, above. Acid treatment only.

\section{WIS-1316. Peterson Slough}

$840 \pm 80$

Livingstone core, $5 \mathrm{~cm}$ diam, from Peterson Slough, Becker Co $\left(46^{\circ}\right.$ $\left.58^{\prime} \mathrm{N}, 95^{\circ} 19^{\prime} \mathrm{W}\right)$. Coll Feb 1981 by J C Almendinger et al; subm by J C Almendinger. Calcareous algal copropel with occasional shell, 40 to $50 \mathrm{~cm}$ below sediment surface. Water depth $390 \mathrm{~cm}$; sediment thickness $12 \mathrm{~m}$ over glacial outwash. Same observations as for WIS-1303, above. Acid treatment only.

\section{WIS-1317. Lydick Lake}

$3760 \pm 90$

Livingstone core, $5 \mathrm{~cm}$ diam, from Lydick Lake, Cass Co $\left(47^{\circ} 23^{\prime} 30^{\prime \prime}\right.$ $\left.\mathrm{N}, 94^{\circ} 25^{\prime} \mathrm{W}\right)$. Coll Feb 1981 by J C Almendinger et al; subm by J C Almendinger. Algal copropel, 300 to $310 \mathrm{~cm}$ below sediment surface. Water depth $482 \mathrm{~cm}$; sediment thickness $5 \mathrm{~m}$ over glacial outwash. Same observations as for WIS-1315, above. Acid treatment only.

\section{Swift site series}

Livingstone core, $5 \mathrm{~cm}$ diam, from Swift, Roseau Co $\left(48^{\circ} 49^{\prime} \mathrm{N}, 95^{\circ}\right.$ 14' W). Coll Aug 1981 by Svante Bjorck; subm by H E Wright, Jr, Univ Minnesota, Minneapolis. Area is covered with $2 \mathrm{~m}$ beach gravel underlain by $40 \mathrm{~cm}$ peat over lacustrine silt. Dates water level changes in Glacial Lake Agassiz (Prest, 1970). Acid treatment only.

\section{WIS-1324.}

$9350 \pm 100$

Peat from 2 to $5 \mathrm{~cm}$ below beach gravel.

WIS-1325.

$10,050 \pm 100$

Peat from 33 to $38 \mathrm{~cm}$ below beach gravel.

\section{Irvin Lake series}

Livingstone core, $5 \mathrm{~cm}$ diam, from Irvin Lake, Itasca Co $\left(47^{\circ} 08^{\prime} \mathrm{N}\right.$, $93^{\circ} 38^{\prime} \mathrm{W}$ ). Coll Dec 1980 by B C Alwin and E J Cushing; subm by E J Cushing, Univ Minnesota. Depths are measured from water surface. Water depth at coring site was $540 \mathrm{~cm}$. Acid treatment only.

WIS-1337.

$1540 \pm 60$

Algal copropel from 580 to $590 \mathrm{~cm}$ depth. Dates second increase of birch pollen and decrease of white pine pollen.

WIS-1338.

$1950 \pm 70$

Algal copropel from 660 to $670 \mathrm{~cm}$ depth. Dates shift to higher values of birch pollen and lower values of white pine pollen. 
WIS-1341.

$\mathbf{3 1 7 0} \pm \mathbf{8 0}$

Algal copropel from 810 to $820 \mathrm{~cm}$ depth. Dates shift in pine assemblage from higher values of oak and herb pollen to high values of white pine and birch pollen.

WIS-1342.

$\mathbf{5 8 9 0} \pm \mathbf{8 0}$

Algal copropel from 987 to $997 \mathrm{~cm}$ depth. Dates increase in pine pollen and decrease in oak pollen.

WIS-1343.

$7500 \pm 80$

Silty algal copropel, calcareous with some shell fragments from 1110 to $1115 \mathrm{~cm}$ depth. Date marks decrease in red/jack pine pollen and increase in oak pollen.

\section{Billy's Lake series}

Livingstone core, $2.5 \mathrm{~cm}$ diam, from Billy's Lake, Morrison Co $\left(46^{\circ}\right.$ $16^{\prime} \mathrm{N}, 94^{\circ} 33^{\prime} \mathrm{W}$ ) coll by G L Jacobson, Jr; subm by E J Cushing. Depths are measured from water surface. Water depth at core site $180 \mathrm{~cm}$. Series will provide dates of Holocene movement of prairie-forest border through site (Jacobson, 1979).

WIS-1364.

$2960 \pm 70$

Marly copropel from 400 to $410 \mathrm{~cm}$ depth.

WIS-1365.

$4590 \pm 70$

Marly copropel with fine plant detritus from 600 to $610 \mathrm{~cm}$ depth.

WIS-1366.

$6870 \pm 80$

Marly copropel with fine plant detritus (Ceratophyllum leaves) from 800 to $810 \mathrm{~cm}$ depth.

WIS-1367.

$10,650 \pm 100$

Silty copropel from 1000 to $1010 \mathrm{~cm}$ depth.

New York

\section{Burden Lake series}

Livingstone core, $5 \mathrm{~cm}$ diam, from Burden Lake, Rensselaer Co $\left(42^{\circ}\right.$ $36^{\prime} 16^{\prime \prime} \mathrm{N}, 73^{\circ} 34^{\prime} \mathrm{W}$ ) coll by D C Gaudreau et al; subm by T Webb, III and D C Gaudreau. Depths are measured from sediment surface, water depth $11.2 \mathrm{~m}$.

WIS-1360.

$2870 \pm 70$

Gyttja from 250 to $256 \mathrm{~cm}$ depth. Dates appearance of Castarea (chestnut) pollen.

WIS-1361.

$$
4630 \pm 70
$$
pollen.

Gyttja from 520 to $526 \mathrm{~cm}$ depth. Dates decline in Tsuga (hemlock) 
WIS-1362.

$6700 \pm 80$ pollen.

Gyttja from 750 to $756 \mathrm{~cm}$ depth. Dates appearance of Carya (hickory)

WIS-1363.

$8730 \pm 90$

Gyttja from 980 to $986 \mathrm{~cm}$ depth. Dates base of core.

\section{Wisconsin}

\section{Lima Bog series}

Core coll Jan 1980 from Lima Bog, Rock Co $\left(42^{\circ} 48^{\prime} \mathrm{N}, 88^{\circ} 51^{\prime} \mathrm{W}\right)$ and subm by Kent Van Zant, Earlham Coll, Richmond, Indiana. Dated to learn more of postglacial vegetation in $S$ central Wisconsin (Van Zant and Lamb, 1980). Measurements are from bog surface. Samples were very calcareous, requiring lengthy acid treatment. Previous dates from site were reported, WIS-1045 (R, 1980, v 22, p 121), WIS-1131, -1134, -1135 (R, 1981, v 23, p 156-157).

\section{WIS-1275.}

$10,180 \pm 110$

Calcareous gyttja with a few snail shells, 1238 to $1248 \mathrm{~cm}$ depth. Color changed from brown to black from top to bottom in this $10 \mathrm{~cm}$. Picea pollen decreased from $20 \%$ to $5 \%$ during this interval. Pinus pollen peaked at $24 \%$ at base of sample. Quercus pollen increased to $25 \%$.

WIS-1278.

$25,700 \pm 460$

Calcareous varved silt banded yellowish brown and black, 1934 to $1967 \mathrm{~cm}$ depth. Basal $33 \mathrm{~cm}$ in core, dating beginning of sedimentation in basin. (1 5-day count.)

WIS-1319. Morris Creek Site A

$1480 \pm 80$

Wood, $200 \mathrm{~cm}$ depth, from site in Monroe Co $\left(43^{\circ} 48^{\prime} \mathrm{N}, 90^{\circ} 36^{\prime} \mathrm{W}\right)$. Coll Aug 1981 and subm by J C Knox, Univ Wisconsin-Madison. Dates late Holocene river channel system that was adjusted to flood and erosional processes representative of very late Holocene climate and vegetation conditions (Knox, McDowell, and Johnson, 1981).

\section{WIS-1320. LaFarge Dam Site I}

$5620 \pm 90$

Wood, $305 \mathrm{~cm}$ depth, from site in Vernon Co $\left(43^{\circ} 36^{\prime} \mathrm{N}, 90^{\circ} 38^{\prime} \mathrm{W}\right)$. Coll July 1981 and subm by J C Knox. Date is max age for relict paleochannel and demonstrates that in larger valley floors of Kickapoo drainage system, much of early Holocene alluvium was removed by late Holocene channel lateral migration (Knox, McDowell, and Johnson, 1981).

WIS-1326. McCoy Site B $7840 \pm 90$

Wood, $270 \mathrm{~cm}$ depth, from site in Monroe Co $\left(43^{\circ} 45^{\prime} \mathrm{N}, 90^{\circ} 35^{\prime} \mathrm{W}\right)$. Coll Aug 1981 and subm by J C Knox. Dates early Holocene river channel system. Small capacity of channel cross-sec indicates that high-frequency floods were significantly smaller than prevailing flood conditions that occurred after ca $6000 \mathrm{yr}$ BP (Knox, McDowell, and Johnson, 1981). 
WIS-1332. Cox Site C

$2540 \pm 70$

Wood, $245 \mathrm{~cm}$ depth, from site in Monroe Co $\left(43^{\circ} 46^{\prime} \mathrm{N}, 90^{\circ} 33^{\prime} \mathrm{W}\right)$. Coll Aug 1981 and subm by J C Knox. Dates very late Holocene river channel system that was apparently adjusted to frequent large floods (Knox, McDowell, and Johnson, 1981).

WIS-1333. Warner Creek Site A

$6180 \pm 80$

Wood, $155 \mathrm{~cm}$ depth, from site in Vernon Co $\left(43^{\circ} 38^{\prime} \mathrm{N}, 90^{\circ} 32^{\prime} \mathrm{W}\right)$. Coll Aug 1981 and subm by J C Knox. Dates late Holocene river channel system that was adjusted to frequent large floods (Knox, McDowell, and Johnson, 1981).

\section{WIS-1334. Powell Site 2}

$1110 \pm 70$

Wood, $196 \mathrm{~cm}$ depth, from site in Monroe Co $\left(43^{\circ} 44^{\prime} \mathrm{N}, 90^{\circ} 36^{\prime} \mathrm{W}\right)$. Coll Aug 1981 and subm by J C Knox. Dates very large capacity late Holocene river channel system. Large capacity implies adjustment to frequent large floods that approach magnitude of large contemporary floods adjusted to agricultural land use.

\section{Platte Ri series}

Samples taken from Bollant site, on bank of Platte R, Grant Co $\left(42^{\circ}\right.$ $55^{\prime} 26^{\prime \prime} \mathrm{N}, 90^{\circ} 30^{\prime} 15^{\prime \prime} \mathrm{W}$ ). Coll 1981 and subm by J C Knox (Knox, McDowell, and Johnson, 1981).

WIS-1380.

$6000 \pm 90$

Woody fragments, from core 152 to $168 \mathrm{~cm}$ below surface, $90 \mathrm{~m}$ from river bank (Bollant 1). Dates relatively large river channel adjusted to climatic episode with relatively frequent large floods.

WIS-1381.

$1200 \pm 70$

Small $\log , 7.5 \mathrm{~cm}$ diam, from bank exposure, $195 \mathrm{~cm}$ below bank surface (Bollant 2). Dates period of active lateral erosional activity by late Holocene channel system.

WIS-1383. Kickapoo Cemetery

$28,900 \pm 650$

Silty peat, 1390 to $1440 \mathrm{~cm}$ taken near NE corner of Kickapoo Center Cemetery, Vernon Co $\left(43^{\circ} 29^{\prime} \mathrm{N}, 90^{\circ} 42^{\prime} \mathrm{W}\right)$. Coll July 1981 and subm by J C Knox. Date supports interpretation that Woodfordian substage $(20,000+$ to ca $12,000 \mathrm{yr}$ BP $)$ was time of major hillslope erosion and basal hillslope colluviation in Driftless Area of SW Wisconsin. Peat growth and hillslope stability between 20,000 to $40,000 \mathrm{yr}$ BP is also consistent with observation in Pecatonica valley on SE margin of Driftless Area (Knox, Clayton, and Mickelson, 1982; Wittecar and Davis, 1982). (1 6-day count.)

WIS-1397. White Clay Lake Marsh $\quad \mathbf{6 2 0} \pm \mathbf{7 0}$

Wood (Thuja occidentalis) from White Clay Lake Marsh $\left(44^{\circ} 47^{\prime} \mathrm{N}\right.$, $88^{\circ} 24^{\prime} \mathrm{W}$ ) in Shawano Co. Coll by F Madison; subm by A M Swain, Univ Wisconsin-Madison. From marl sediment 35 to $45 \mathrm{~cm}$ below base of beach ridge and 75 to $85 \mathrm{~cm}$ from ridge surface. Date helps establish chronology for pollen diagram from this site. 


\section{Lake Mendota series}

Livingstone core, $5 \mathrm{~cm}$ diam from Lake Mendota, Dane Co $\left(43^{\circ} 06^{\prime} \mathrm{N}\right.$, $\left.89^{\circ} 25^{\prime} \mathrm{W}\right)$. Coll Feb 1982 and subm by A M Swain. Dates from 3 of 4 cores coll along transect of varying water depth in University Bay should indicate times of low and high water levels during Holocene. Acid treatment only.

WIS-1382.

$11,400 \pm 100$

Decomposed peat from 26 to $32 \mathrm{~cm}$ in $70 \mathrm{~cm}$ core (Core A) coll at water depth $70 \mathrm{~cm}$. Peat was covered by sand and organic lake sediment. Date marks end of high-water level of Lake Mendota.

WIS-1386.

$3430 \pm 70$

Sandy marl sediment from 53 to $73 \mathrm{~cm}$ in $130 \mathrm{~cm}$ core (Core B) coll at water depth $2.7 \mathrm{~m}$. Sample overlies transition from sandy to silty sediment. Date marks return of higher water level in lake.

WIS-1387.

$11,100 \pm 110$

Silty marl sediment from 73 to $93 \mathrm{~cm}$ in same core as WIS-1386, immediately underlying change from sandy to silty sediment. Sample should date end of high water level of lake.

WIS-1406.

$\mathbf{3 2 4 0} \pm \mathbf{8 0}$

Marl lake sediment from 50 to $60 \mathrm{~cm}$ in $5 \mathrm{~m}$ core (Core D) coll at water depth $3.7 \mathrm{~m}$, overlying $10 \mathrm{~cm}$ layer of sandy marl. Date is estimate of return of higher lake level.

WIS-1407.

$6980 \pm 80$

Marl lake sediment from 80 to $90 \mathrm{~cm}$ in $5 \mathrm{~m}$ core (Core D), underlying $10 \mathrm{~cm}$ layer of sandy marl. Date from this level should mark end of higher lake level.

WIS-1384. Caballo Muerto $\quad \mathbf{3 4 1 0} \pm \mathbf{7 0}$

Peat from Caballo Muerto, S of Laguna Guayatoyoc, alt $3800 \mathrm{~m}$, Jujuy prov $\left(24^{\circ} 00^{\prime} \mathrm{S}, 66^{\circ} 00^{\prime} \mathrm{W}\right)$. Coll April 1981 and subm by Vera Markgraf, Inst Arctic and Alpine Research, Boulder, Colorado. Sample at 60 to $70 \mathrm{~cm}$ depth, interbedded with sand layers underlying artifacts. Date to be used in paleoclimatic analysis of Holocene sec.

WIS-1385. Guayantayoc

$2540 \pm 70$

Peat from Guayantayoc, W of Laguna Pozuelos, alt $3750 \mathrm{~m}$, Jujuy prov $\left(22^{\circ} 20^{\prime} \mathrm{S}, 66^{\circ} 10^{\prime} \mathrm{W}\right)$. Coll April 1981 and subm by V Markgraf. From peat sec eroded by arroyo underlain by lacustrine sediments. Date to be used in paleoclimatic analysis of lacustrine and peat sec.

WIS-1388. Cumbres Calchaquies

$1190 \pm 70$

Peat from Cumbres Calchaquies, Lagunas Huaca Huasi, alt $4250 \mathrm{~m}$, Tucuman prov $\left(26^{\circ} 44^{\prime} \mathrm{S}, 65^{\circ} 44^{\prime} \mathrm{W}\right)$. Coll May 1981 by Stephen Halloy, Inst Lillo, Tucuman, and subm by V Markgraf. From peat sec at 100 to 
$110 \mathrm{~cm}$ depth near small lakes of glacial origin. Date to be used in paleoclimatic analysis of peat sec.

WIS-1389. El Aguilar Mine

$2120 \pm 70$

Peat from El Aguilar Mine, alt $3900 \mathrm{~m}$, Jujuy prov $\left(23^{\circ} 05^{\prime} \mathrm{S}, 65^{\circ} 45^{\prime}\right.$ W). Coll April 1981 and subm by V Markgraf. From 140 to $150 \mathrm{~cm}$ in peat sec cut by arroyo. Date to be used along with previous dates for paleoclimatic profile from area on which there is no information on 10,000-yr history.

\section{WIS-1390. La Mejicana Bog}

$9490 \pm 100$

Peat from La Mejicana Bog and E slope of Sierra Famatina, alt $2450 \mathrm{~m}$, La Rioja prov $\left(28^{\circ} 44^{\prime} \mathrm{S}, 67^{\circ} 37^{\prime} \mathrm{W}\right)$. Coll April 1981 and subm by $\mathrm{V}$ Markgraf. From peat sec cut by arroyo. Date to be used in paleoclimatic analysis.

\section{Rattle Lake series}

\section{Canada}

Three Livingstone cores, $5 \mathrm{~cm}$ diam, from Rattle Lake, Kenora dist, Ontario $\left(49^{\circ} 21^{\prime} \mathrm{N}, 92^{\circ} 42^{\prime} \mathrm{W}\right)$. Coll by $\mathrm{S}$ Bjorck; subm by $\mathrm{H} \mathrm{E}$ Wright, $\mathrm{Jr}$, Univ Minnesota. Water depth $525 \mathrm{~cm}$. All measurements from water surface. Dates will be used to calculate deglaciation, early plant migration, and possible effects during hypsithermal (Prest, 1970). Acid treatment only.

WIS-1327.

$11,110 \pm 110$

Clay gyttja with some coarse organic matter from 1266 to $1271 \mathrm{~cm}$ depth.

WIS-1328.

$$
10,150 \pm 100
$$

Clay gyttja from 1242 to $1245 \mathrm{~cm}$ depth.

\section{WIS-1379.}

$$
10,850 \pm 100
$$

Clay gyttja from 1255 to $1260 \mathrm{~cm}$ depth.

WIS-1395.

$$
6500 \pm 80
$$

Gyttja, blackish brown to rust-colored, from 1025 to $1030 \mathrm{~cm}$ depth. Dates highest abundance of white pine pollen.

WIS-1396.

$7150 \pm 80$

Gyttja, brownish-black, from 1070 to $1075 \mathrm{~cm}$ depth. Dates immigration of white pine.

W]IS-1398.

$8420 \pm 90$

Gyttja, dark brown from 1205 to $1210 \mathrm{~cm}$ depth. Dates immigration of white pine.

\section{Sioux Pond series}

Three Livingstone cores, $5 \mathrm{~cm}$ diam, from Sioux Pond, Kenora dist, Ontario $\left(49^{\circ} 56^{\prime} \mathrm{N}, 91^{\circ} 34^{\prime} \mathrm{W}\right)$. Coll Aug 1981 by S Bjorck; subm by $\mathbf{H}$ 
E Wright, Jr. Dates will be used in same way as for Rattle Lake series, above. Acid treatment only.

WIS-1329.

$9740 \pm 100$ surface.

Clayey gyttja with shell fragments from 549 to $552 \mathrm{~cm}$ below peat

WIS-1393.

$6690 \pm 80$

Coarse-detritus gyttja, dark brown, from 430 to $435 \mathrm{~cm}$ below peat surface. Dates immigration of white pine.

WIS-1394.

$\mathbf{5 4 7 0} \pm \mathbf{8 0}$

Fine to coarse detritus gyttja with brown and dark-brown lamina, from 395 to $400 \mathrm{~cm}$ below peat surface. Dates highest abundance of white pine pollen.

\section{Cristal Lake series}

Livingstone core, $5 \mathrm{~cm}$ diam, from Cristal Lake, Kenora dist, Ontario $\left(52^{\circ} 07^{\prime} \mathrm{N}, 90^{\circ} 05^{\prime} \mathrm{W}\right)$. Coll by S Bjorck, subm by $\mathrm{H} \mathrm{E}$ Wright, Jr. Water depth $260 \mathrm{~cm}$. Dates will be used in same way as for Rattle Lake series, above. Acid treatment only.

WIS-1330.

$6720 \pm 80$

Gyttja with shell fragments from 786 to $791 \mathrm{~cm}$ below water surface.

WIS-1392.

$6370 \pm 70$

Dark-brown gyttja, from 760 to $765 \mathrm{~cm}$ below water surface. Dates hypsithermal max.

\section{Indian Lake}

Three Livingstone cores, $5 \mathrm{~cm}$ diam, from Indian Lake, Kenora dist, Ontario $\left(50^{\circ} 56^{\prime} \mathrm{N}, 90^{\circ} 27^{\prime} \mathrm{W}\right)$. Coll Aug 1981 by S Bjorck; subm by $\mathrm{H}$ E Wright, Jr. All measurements from water surface. Water depth $2 \mathrm{~m}$. Dates will be used in same way as for Rattle Lake series, above. Acid treatment only.

WIS-1331.

$9140 \pm 100$

Clayey gyttja from 884 to $887 \mathrm{~cm}$ depth.

WIS-1399.

$6560 \pm 80$

Algal gyttja, greenish brown from 730 to $735 \mathrm{~cm}$ depth. Dates hypsithermal max.

WIS-1401.

Algal gyttja, dark brown, from 810 to $815 \mathrm{~cm}$ depth. Dates immigration of white pine.

\section{Leech Fen series}

Livingstone cores, $5 \mathrm{~cm}$ diam, from Leech Fen, Labrador North dist, Labrador $\left(53^{\circ} 10^{\prime} \mathrm{N}, 58^{\circ} 45^{\prime} \mathrm{W}\right)$ by G A King and D R Foster; subm by G A King, Univ Minnesota. String fen is $200 \mathrm{~m}$ long, with rise of $180 \mathrm{~cm}$ 
from fen base to top. Cores were taken at various intervals up fen to determine its stratigraphic relationships. Acid treatment only.

WIS-1353.

$1210 \pm 70$

WIS-1353 to -1355 are from core taken from 1st pool at lower end of Leech Fen. Core consists of $50 \mathrm{~cm}$ of peat overlying $90 \mathrm{~cm}$ of lake sediment. This sarnple, 15 to $19 \mathrm{~cm}$ below water surface in pool, and 3 to $7 \mathrm{~cm}$ below top of peat surface, dates top of peat deposit in pool.

WIS-1354.

$4530 \pm 70$

58 to $63 \mathrm{~cm}$ below water surface in Pool 1 , dating transition from lake sediment to peat.

WIS-1355.

$4440 \pm 60$

Basal wood and woody peat, from 73 to $76 \mathrm{~cm}$ in core from pool 2/3 of distance up fen, dates initiation of peat deposition at this loc (Core 25).

WIS-1356.

$2900 \pm 70$

Sample from basal peat layer, 75 to $79 \mathrm{~cm}$ deep, of uppermost pool in fen; dates initiation of peat deposition at this loc (Core 17).

WIS-1357.

$7110 \pm 80$

Final date from Pool 1 core from base, 144 to $148 \mathrm{~cm}$ below water surface. Date indicates when lake sediment deposition began within this shallow bay of Leech Lake.

WIS-1403.

$760 \pm 70$

Sedge peat from base, 27 to $32 \mathrm{~cm}$, of Core 20 coll in transition area between fen and forest vegetation at upslope end of fen; dates beginning of peat cleposition at this loc.

WIS-1404.

$410 \pm 70$

Sample from 31 to $36 \mathrm{~cm}$ below water surface and $1 \mathrm{~cm}$ below waterpeat interface (Core 24). Core was coll from pool 2/3 of distance up fen.

\section{REFERENCES}

Alex, L M, 1979, 39Bu2: A fortified site in western South Dakota: Archaeol Soc South Dakota Newsletter, v 9, no. 3, p 3-7.

Bender, M M, Baerreis, D A, and Bryson, R A, 1980, University of Wisconsin radiocarbon dates XVII: Radiocarbon, v 22, p 115-129.

Bender, M M, Baerreis, D A, Bryson, R A, and Steventon, R L, 1981, University of Wisconsin radiocarbon dates XVIII: Radiocarbon, v 23, p 145-161. p 83-100. 1982, University of Wisconsin radiocarbon dates XIX: Radiocarbon, v 24

Chapman J and Shea, A B, 1981, The archaeobotanical record: Early Archaic period to contact in the lower Little Tennessee $R$ valley: Tennessee Anthropologist, $v 6$, no. $1, \mathrm{p} 61-84$.

Davis, M B, 1958, Three pollen diagrams from central Massachusetts: Am Jour Sci, v 256, p 540-570.

Delcourt, P A, 1980, Quaternary alluvial terraces of the Little Tennessee River, East Tennessee, in Chapman, J, ed, The 1979 archaeological and geological investigations in the Tellico Reservoir: Univ Tennessee Dept Anthropol rept inv, p 110-121.

Hovde, D M, 1981, Archaeological excavations of stone circle sites on the southeastern Black Hills periphery and Cheyenne River drainage. South Dakota Archaeol Research Center, Contract Inv Rept no. 36A, Ft Meade. 
Jacobson, G L, 1979, The paleoecology of white pine (pinus strobus) in Minnesota: Jour Ecol, v 67, p 697-726.

Knox, J C, Clayton, L, and Mickelson, D M, 1982, Quaternary history of the driftless area: Field trip guide book no. 5, Wisconsin Geol Nat Hist Survey, Madison, 169 p.

Knox, J C, McDowell, P F, and Johnson, W C, 1981, Holocene fluvial stratigraphy and climatic change in the driftless area, Wisconsin, in Mahoney, W C, ed, Quaternary paleoclimate: Norwich, England, Geoabs Ltd, p 107-127.

Lamb, H F, 1980, Late Quaternary vegetational history of southeastern Labrador: Arctic and Alpine Research, v 12, no. 2, p 117-135.

Longin, R, 1971, New method of collagen extraction for radiocarbon dating: Nature, v 230, p 241-242.

Lowdon, J A and Blake, Weston, Jr, 1975, Radiocarbon dates, Labrador: Geol Survey Canada Paper, v 75-7, p 1-32.

Morrison, A, 1970, Pollen diagrams from interior Labrador: Canadian Jour Bot, v 98, p 1957-1975.

Overstreet, D F, 1981, Archaeological inventory and evaluation at Exxon Minerals Company, Crandon Project site in Forest and Langlade Counties, Wisconsin: Great Lakes Archaeol Research Center, Inc, Rept Inv no. 107

Prest, V K, 1970, Quaternary geology of Canada, in Geology and Economic Minerals of Canada, ed no. 5: Geol Survey Canada, Econ Geol Rept no. 1, p 677-764.

Reeder, R L, 1982, The Feeler site, 23MS12: A multicomponent site in the central Gasconade Basin: Missouri State Hwy Comm rept.

Salzer, J, ms, 1969, An introduction to the archaeology of Northern Wisconsin: Unpub PhD dissert, Southern Illinois Univ, Carbondale, Illinois.

1974, The Wisconsin North Lakes Project: A preliminary report, in Johnson, E, ed, Aspects of Upper Great Lakes anthropology-Essays in honor of Lloyd A Wilford: Minnesota State Hist Soc pubs, St Paul.

Stoltman, J B, 1979, Middle Woodland stage communities of southwestern Wisconsin, in Brose, D S and Grever, N, eds, Hopewell archaeology: Kent University Press, p 122-139.

Van Zant, K L and Lamb, W M, 1980, Post glacial vegetational reconstructions in south-central Wisconsin, based on a core from Lima Bog, Rock County, Wisconsin: Geol Soc America (abs), v 12, p 259.

Whittecar, G R and Davis, A M, 1982, Sedimentology and palynology of Middle Wisconsin deposits in the Pecatonica River Valley, Wisconsin and Illinois: Quaternary Research, v 17, p 228-240. 